McCutcheon, Mark A. "Frankenstein as a figure of globalization in Canada's postcolonial popular culture." Continuum 25.5 (2011): 731-42.

This is a post-print version of an article published in Continuum: Journal of Media \& Cultural Studies. The definitive published version is available from Taylor \& Francis. AU students and personnel can access the published version via this direct link:

http://0-www.tandfonline.com.aupac.lib.athabascau.ca/doi/full/10.1080/10304312.2011.590577

Other readers can find the published version either via their institution's library subscription to the Taylor \& Francis Library database, or via this link:

http://www.tandfonline.com/doi/pdf/10.1080/10304312.2011.590577

\title{
Frankenstein as a figure of globalization in Canada's postcolonial popular culture
}

\author{
Mark A. McCutcheon \\ Faculty of Humanities \& Social Sciences, Athabasca University, Athabasca, Canada
}

\begin{abstract}
This essay analyzes the cultural functions of Frankenstein as a figure of globalization in postcolonial popular culture. Focusing on the case of Canadian film production, I begin by contextualizing Canadian film as a postcolonial site of globalized popular culture, characterized by 'technological nationalism'. In this context, I consider three Canadian films that adapt Mary Shelley's Frankenstein to represent globalization. David Cronenberg's Videodrome (1983) borrows from Frankenstein and Marshall McLuhan to critique new media in the 'global village'; Robert Lepage's Possible Worlds (2000) quotes from the Universal Frankenstein film; and Mark Achbar and Jennifer Abbot's The Corporation (2003) uses Frankenstein as a recurring analogy for the modern corporation. This essay signals a starting point for a more interculturally and transnationally comparative investigation of how Frankenstein adaptations provide a powerful repertoire of representational devices for a postcolonial theory of globalization.
\end{abstract}

In July 2007, I was at a Canadian Studies conference in Marburg, Germany, where the opening presentations both referred to Mary Shelley's Frankenstein. A team of graduate students read excerpts from the stories of Inuit author Alootook Ipellie, one of which involved shamans assembling their spirit helpers into 'our version of Frankenstein' (1993, 37-40). Then, in the keynote address, Paul Adams talked about transnational ideas of home in the context of what he called 'the Frankenstein of globalization'. Following the connections inspired by this scene of unexpectedly conjoined images, I suggest that representing globalization as a Frankenstein monster is not so much uniquely Canadian as productively postcolonial with reference to Canadian popular culture. First, I contextualize Canadian film as a postcolonial site of globalized popular culture, characterized by a tradition of 'technological nationalism' (Charland 1986, 206). I then discuss the appearance of Frankenstein figures in three Canadian films: Videodrome (1983), Possible Worlds (2000), and the documentary The Corporation (2003). This essay signals a starting point for a more interculturally and transnationally comparative investigation of how Frankenstein adaptations provide a powerful repertoire of representational devices for a postcolonial theory of globalization.

\section{Canadian popular culture: 'a paradigm case of media imperialism'}

As Aniko Bodroghkozy writes, 'Canada has been served up as a paradigm case of media imperialism. ... according to much of Canadian communications theory, Canada wallows in dependency and dubious sovereignty' $(2002,570)$. On the political, economic, and cultural fronts, Canada is dependent on US interests and industry in material ways that compromise the northern state's political sovereignty and render its relationship to its southern neighbour ambivalent and conflicted. This relationship is analysed anxiously from north of the 49th parallel, while being ignored or misrecognized from the south: 'Americans have an amazing tendency to assimilate Canadian work to American experience. . . . Canada doesn't exist as a national entity to the U.S.' (Greyson, quoted in Marks 2005, 198). 
In a global context, the US entertainment industry has become almost synonymous with 'popular culture' itself. Hollywood was one of the first globalized cultural industries, and Canada's relationship with Hollywood is long-standing and conflicted (see Gasher 2002). Canada provides Hollywood with cheap and abundant film industry services, labour, and resources. Canadian shooting locations are not just conveniently close to Hollywood, but actively promote themselves as stand-ins for US locations, as sites primed for colonization, 'largely unpopulated place[s] full of scenic wonders and infinite resources' (Rutherford 2005, 106). Turning from production to consumption, English-speaking Canadians consume far more American than domestic media products. The predominance of US content on Canadian screens is about more than what Bodroghkozy rightly calls 'our taste for American popular culture' $(2002,570)$; it is an effect of neo-imperial trade economics: US media companies export their products to foreign carriers for a fraction of what they charge US carriers, making it cheaper for Canadian broadcasters to buy US imports than finance domestic production, however popular that domestic content may be.

As Peter Grant and Chris Wood explain, these 'curious economics' of globalized popular culture have occasioned state policies that protect cultural sovereignty and diversity of expression, which would otherwise be destroyed by narrow adherence to free-market ideology $(2004,22)$. Canada has kept its own cultural sector exempt - so far - from free-trade agreements, and developed a policy toolkit for stimulating domestic popular cultural production, on the premise that state investment in cultural production builds nationalism and sovereignty (386-88). Canada's toolkit of public media, content quotas, and funding agencies they describe also includes some instruments for supporting Canadian scholarly as well as popular culture; however, Social Sciences and Humanities Research Council (SSHRC) funding for Canadian cultural studies research has only been formalized within the last decade. This belated recognition of Canadian cultural studies is a symptom of the field's own postcolonial historical neglect by a national intellectual elite that has privileged Arnoldian ideals of culture over and against American industries of entertainment, seen as a threat to Canada's national sovereignty (Rutherford 2005, 105).

\section{A postcolonial perspective on Canadian popular culture}

In light of English Canada's 'paradigm case of media imperialism', Oliver Boyd-Barrett's thesis of 'media imperialism' remains relevant to Canadian popular cultural studies. Yet in communication and media studies which have produced much of the literature on Canadian popular culture, BoydBarrett's thesis has been criticized as too neglectful of the ambiguities of 'colonial' appropriations, and too closely tied to 'territorial annexation' (Gasher, Lorimer, and Skinner 2007, 287-88).

However, cultural and literary studies have picked up and developed the media imperialism thesis in investigations informed by interconnected theories of nationalism, postcolonialism, and globalization (see How Canadians Communicate III (Beaty et al. 2010) and Canadian Cultural Studies (Mookerjea, Szeman, and Farschou 2009).

Recent postcolonial readings of Canadian popular culture sustain the media imperialism thesis not despite but due to Canada's ambivalent relations to US popular culture. Laura Marks employs Homi Bhabha's model of pedagogy and performance in national identity to explore how 'the little performances that constitute Canada insinuate themselves into the massive national fiction that constitutes the United States' $(2005,197)$. Bodroghkozy's essay, like more recent work by Patricia Hughes-Fuller, draws on Benedict Anderson and Graeme Turner; Hughes-Fuller investigates the 'postcolonial Gothic' subtext of Canada's hockey culture (2010,277). In a critique of Canadian cultural policy, Donna Pennee draws on postcolonialists like Len Findlay and Gayatri Chakravorty Spivak to show how Canadian foreign policy has deployed "culture" from the Cold War to "the Market Wars," from the explicitly "ideological" threats to national security, to the explicit but apparently non-ideological threats of global capitalism' $(1999,196)$. Diana Brydon's recent work has forged important links between postcolonialism and globalization studies; alluding to the vexed question of national sovereignty $(2004,703)$ and the US government's targeting of postcolonialism 'as yet another enemy of US patriotism' (693), Brydon succinctly reaffirms the urgency with which 'postcolonial critique continues to pose a challenge to the new incarnations of Empire' (693). 
The postcolonial perspectives developed in research like this represent one way of what Pennee calls 'doing the national differently' $(2004,83)$, by adding a nuanced sense of cultural and economic globalization to Canadian cultural studies' established materialist focus on the institutions and media of cultural production. As I have argued elsewhere, the constant political pressure of US trade interests on Canadian policy and national sovereignty, in everything from copyright to health care and water, validates the media imperialism thesis' implicit link between cultural trade and territorial annexation: 'the difference between media and political imperialism seems to collapse when viewed from a Canadian perspective' $(2009,9)$.

\section{'The Frankenstein of globalization'}

This sketch of media imperialism in Canada sets the stage for discussion of films that adapt Frankenstein to comment on globalization, understood (following Appadurai 1990 and Sassen 2000) as an intensification of international flows of money and labour, whose chief beneficiaries are multinational corporations. Frankenstein has long provided popular culture with a figure for representing backfire crises, a figure derived, as Chris Baldick argues, from the novel's 'technological reduction . . . as an uncanny prophecy of dangerous scientific inventions' $(1987,7)$. The novel's reductive technological interpretations and adaptations have proven very productive - in large part due to the popular perception of almost any technological threat as an inherently global threat. Recall that Dr. Frankenstein imagines, as the ultimate result of his research, a 'race of devils [that] would be propagated upon the earth' (Shelley 1818, 190).

Frankensteinian anxieties have shaped popular ideas of globalization ever since Shelley's novel began its 'career as an object of rhetorical allusion' (Baldick 1987, 60) in 1824, in British parliamentary debates over abolition (Hitchcock 2007, 89). Since then, Frankenstein has been invoked - predominantly by conservative commentators (St Clair 2004, 373) - as a caution towards typically global issues: from nuclear power (Sullivan, quoted in Morton 2002, 56), to file-sharing: 'digital piracy is Hollywood's own digital Frankenstein' (Sickels 2009, 22). Today's globalized, Orwellian 'war on terror' has prompted allusions from across the political spectrum, as in Arundhati Roy's commentary on the Mumbai terror attacks of December 2008:
As recruiting agents for America's jihad against the Soviet Union, it was the job of the Pakistan army and the ISI to nurture and channel funds to Islamic fundamentalist organizations. Having wired up these Frankensteins and released them into the world, the US expected it could rein them in like pet mastiffs whenever it wanted to. $(2008,27)$

Less pronounced than the conservative use of Frankenstein as political allusion is a tenacious progressive use. Marx defined capital itself, manufactured and monstrous, as 'dead labour which, vampire-like, lives only by sucking living labour' (quoted in Baldick 1987, 130). Marxist literary criticism has identified Frankenstein's monster with the industrial working class (Montag 2000, 388), and queried the political economy of the novel's production during a period of Luddite agitation (O’Flinn 1983, 197).

In popular culture, as Susan Tyler Hitchcock writes, the Depression prompted analogously progressive references: together with the horrors of World War One and slavery's legacy, Depression anxieties contextualized the success of James Whale's 1931 Frankenstein movie in its time (2007, 142-45). And Frankensteinian representations of corporate business after the Depression resonate profoundly today. For example, Mitchell Dawson's 1930 article 'Frankenstein, Inc.' criticizes the corporate takeover of law practice, and expresses his suspicion of corporations in most sectors, such as 'the gigantic press Frankensteins which now control the news and public opinion' (276). Dawson envisions 'the corporate Frankenstein' (279) inaugurating an age in which 'law and government will be nullified' - an age we might recognize as that of present-day globalization.

Globalization theory privileges technology in its models of transnational political and cultural economy, chiefly for facilitating the mobile exploits of capital (see Appadurai 1990, 297-98; Sassen 2000, 222). Jonathan Beller reads the technological imperative of globalization in the eminently Frankensteinian pop culture image of the cyborg: a 'limit-figure for the conjunction of the global and 
the local - the intersecting of the human being from anywhere in the world . . . and the technology (military, industrial, and informational) endemic to transnational capitalism' $(1996,195)$.

Postwar globalization, an intensification of the technologized flow and corporate concentration of capital, thus provides a new, complex, and moving target for Frankensteinian figures and tropes. In Canadian film, such tropes are attentive to the functions and powers of media systems and corporate structure that consolidate globalization.

In a critical study of Harold Innis, Marshall McLuhan, and George Grant, Arthur Kroker elaborates a theory of Canadian postcolonialism avant la lettre, identifying these thinkers as representatives of a 'Canadian discourse on technology' that 'thrusts us into the centre of a debate of world significance' over issues of 'neotechnical capitalism' and 'global media system[s]' (1984, 13, 18) - issues of postcolonial globalization. In McLuhan's work specifically, Kroker sees an ambivalent 'technological humanism', both hope for a wired Utopia and anxiety over modernity's 'processed world of technology' (60).

Contrary to its popular reception, McLuhan's image of the 'global village' is not Utopian, but dystopian: a 'whirlwind of violence' sown by 'the dragon's teeth of technological change' (1969, 243). He figures 'technology' as what Timothy Morton calls a 'Frankenpheme': a fragmentary 'element of culture . . . derived from Frankenstein, but . . . less than a work of art in . . scale' (2002, 48). The dread with which McLuhan theorizes the 'global village' and technology in general (as in his first book's references to 'Frankenstein fantasies' $(1951,100))$ shows that the spectre of Frankenstein haunts his theory of the 'global village' in ways that have been amplified by adaptations of his work by later Canadian artists, like director David Cronenberg.

\section{'You'll have to learn to live in a very strange new world'}

Cronenberg's 1983 movie Videodrome vividly dramatizes the postcolonial use of Frankenstein

figures to represent globalization in a cyberpunk horror story about media imperialism, including one character who openly parodies McLuhan. Cronenberg's early 'cult' films from the 1970s and '80s are almost all variations on a Frankenstein theme: in Rabid (1977), The Brood (1979), and Scanners (1981), dubious corporate research and development breeds grotesque human monsters. In Videodrome, James Woods plays Max Renn, a TV station owner who starts hallucinating after watching an S\&M TV programme called Videodrome. Renn seeks answers from Brian O'Blivion, the inventor of 'the Videodrome signal', and from Barry Convex, CEO of the Spectacular Optical corporation, 'an enthusiastic global citizen' that makes 'eyeglasses for the third world, missile guidance systems for NATO' - and Videodrome. Max becomes a murderous pawn played between O'Blivion's techno-utopian 'Cathode Ray Mission' (which gives TV access to the homeless) and Spectacular Optical, which plans to broadcast Videodrome as part of a vaguely described mediaimperialist plot either to incapacitate the North American populace into zombie-like stupor, or to incite it to violent mobilization. Turning on his would-be programmers, Max finally immolates himself as an apotheosis of 'the video word made flesh'.

Videodrome dramatizes McLuhan's claim that new media are turning 'the real world into science fiction' $(1964,54-55)$. Max Renn enacts the kind of subjectivity that McLuhan posits as symptomatic of the 'global village': a postmodern subjectivity, colonized and reprogrammed by new media.

Woods' performance renders ironic Renn's fate as the test subject for a transnational media empire, in that he's a Hollywood star leading in a Canadian film made with federal arts funding. O'Blivion's character adds more irony to the media-sector satire: he is an open parody of McLuhan. O'Blivion makes cryptic, prophetic claims for television; like McLuhan, he has suffered a brain tumour; and he only ever appears in the film as a 'talking head' on a TV screen. The plot eventually reveals that O'Blivion died prior to the film's action, leaving a library of videotapes as his posthumous, virtual self, making his monologues to Renn uncanny addresses from some monstrously remediated afterlife.

Videodrome represents new media, like video at the time, as tools of globalization that serve the imperialist aspirations of multinational corporations. Cronenberg's 1983 ironic portrayal of corporate social responsibility (in Convex's invocation of 'citizenship'), corporate deployments of 
mass media, and the resulting unevenness of global development (a soft North America, versus the 'rest of the world' turned 'tough' and 'savage') all appear years ahead of the critical theories of globalization that gained currency over a decade later (Appadurai 1990; Jameson and Miyashi 1998). O'Blivion warns Renn that he will 'have to learn to live in a strange new world', signifying the disoriented North America plotted by Spectacular Optical and theorized by McLuhan's violent 'global village'.

Brian O'Blivion's mediatized appearance throughout the film, as an uncanny 'talking head', both parodies McLuhan's ideas about television and gives a cyberpunk twist to the Frankensteinian film trope of the 'brain in a vat'. This trope, like the film's setting in a competitive corporate context, recurs in Robert Lepage's film Possible Worlds (2000), although this film's uses of Frankenstein plot and imagery differ greatly from those in Videodrome.

\section{'There's only one world'}

Possible Worlds follows George Barber, who tries to understand why he seems to lead multiple lives among parallel worlds. Opening shots seem to frame Barber's story retrospectively, showing him as a murder victim whose brain has been stolen. When the investigating detectives learn of Barber's work for 'rival pharmaceutical companies', they suspect Dr. Kleber, a senior researcher at one of the companies, Axon. Their discovery of his guilt immediately follows Barber's own discovery, in dialogue with Kleber, that he lives only as a sentient brain in a jar. Experimental stimuli and randomly accessed memories explain his dreamlike existence among 'possible worlds' that are hauntingly surreal.

Robert Lepage pays homage to Whale's Frankenstein in the fetishistic presentation of Barber's isolated brain, which is not revealed as evidence of his real circumstance until the film's climactic scene, where Barber tells Dr. Kleber that he knows where (and what) he is now. The scenario of the 'brain in a vat' - a 'thought experiment' for cognitive science and philosophical problems in metaphysics and consciousness - is based in Plato's allegory of the cave and Descartes' exercises in doubt, but takes its mise en scène from science fiction, specifically from the 1931 Frankenstein film, in which Fritz stole an 'abnormal brain' for Dr. Frankenstein. Barber's mystified condition as an amputated brain on life support also gruesomely literalizes McLuhan's Frankensteinian claim that with 'electric technology, man extend[s], or set[s] outside himself, a live model of the central nervous system itself' $(1964,65)$.

Possible Worlds leaves the question of Barber's agency ambiguous, but it is ultimately a question overdetermined by the film as recorded medium and scripted production. Videodrome, in contrast, stresses the question of Renn's agency as he descends into the simulacrum's maelstrom. In both films, the plot is driven by a terrifying rift that opens between the protagonist's perception and the world he perceives: a perceptual rift produced and exploited by corporate competition; and eventually perceived by the protagonist, who recognizes in it both his own status as a monstrous commodity and the monstrous institution that manufactured it. Like O'Blivion's talking head, Barber's vat-bound brain appears as an explanatory cause for the plot, but these monstrous subjects are revealed, in their respective diegetic worlds, at opposite points in the films' plots. In Videodrome, O'Blivion appears quite early to catalyse the dissolution of a realistic, corporate setting into a 'strange new world' of hallucinatory disorientation and cruelty. Conversely, in Possible Worlds, Barber's brain is revealed quite late, and crystallizes the resolution of his hallucinatory, disorienting worlds into a realistic, corporate setting of instrumentally rationalized cruelty.

In the resolution of Barber's 'possible worlds' into one cruel world of transnational corporate capital, the film refers ironically to two implied intertexts. Leibniz's claim that this is 'the best of all possible worlds' $(1710,228)$ encounters its pessimistic counter-argument in the subject's reduction to commodity by a world ruled by the profit motive. And the slogan of the alter-globalization NGO, the World Social Forum - that 'another world is possible' (2002) - is affirmed, albeit in an ironic, elegiac way. For all the brutality with which a multinational has exploited him, and in disavowal of the 'one world' that elevates its kind of empire, Barber continues to occupy a multitude of other possible worlds, and so claims an irreducible sovereignty for the subject's inner life. 


\section{'What kind of person is a corporation?'}

The ruthless, Frankensteinian characterization of corporate culture in Possible Worlds is similar to that given in the 2003 documentary The Corporation. One sequence in the film offers its own variation on the commoditized brain in a jar. Over a montage of footage of frenzied shopping mobs, Noam Chomsky delivers a Frankfurt School-style commentary on consumerism: 'The goal for the corporations is to maximize profit and market share, and they also have a goal for their target in the population: they have to be turned into completely mindless consumers of goods they do not want'. The consumer-mob footage cuts to a tracking shot of a solitary man, vacantly watching TV at home. As Chomsky says, 'the ideal is to have individuals who are totally dissociated from one another', this shot zooms in on the TV watcher's close-cropped head and tracks around to reveal a UPC barcode tattoo at the nape of his neck.

In addition to its visual echoes of Frankensteinian brains in other Canadian cinematic vats, this sequence also evokes Orwell's telescreen and Kafka's harrow, as well as McLuhan's 'global village' as a paradoxical real world of science fiction. The scene renders ironic McLuhan's recurring description of electronic media use as 'corporate participation' $(1967,125)$. The Corporation does not cite McLuhan explicitly, but it does much to represent the science-fictional strangeness of economic globalization in ways McLuhan anticipated, from corporations' manipulation of public opinion to their commoditization of life forms. The Corporation's visual collage mixes archival corporate PR clips - promising a 'better life' through 'technology' and 'capitalism' - with reportage and footage of current events, like summits and protests, and original interviews that portray a grim present and project a 'dark future'. The juxtaposition of past images of a Utopian future with current images of a dystopian present thus gives the film a distinctly science-fictional preoccupation with what George Slusser calls 'the Frankenstein barrier' in SF plots: 'where the present, lurking all along, rises up to avenge the sins of our uncreated future' $(1992,128)$.

The film's opening sequence offers some descriptive metaphors for the corporation, as a way to introduce its main argument: that the modern corporation is the deeply flawed but 'dominant institution of our time', an entity legally constructed as a 'person' but legally obliged to pursue profits exclusively. Such 'monstrous obligations' (in the film's phrasing) inculcate dispositions and encourage behaviours that make the personality of the corporate 'person' fit, with uncanny precision, the clinical profile of psychopathy. Among the metaphors offered for the corporation is 'Frankenstein's monster', implied by one interviewee and invoked by another:

\footnotetext{
Off-screen interviewee 1: Corporations are artificial creations; you might say they're monsters, trying to devour as much profit as possible, at anyone's expense.

Off-screen interviewee 2: Dr. Frankenstein's creation has overwhelmed and overpowered him, as the corporate form has done with us.
}

As these voiced-over comments proceed, the film shows a clip from the 1971 B-movie Lady Frankenstein in which the creature strangles its creator. The mix of verbal commentary about 'overpowering creations' and visual footage of monstrous strangulation reproduces a popular 'Frankenpheme', based in the Depression legacy of progressive Frankenstein allusions, which describes the corporate tendency to monopolize as a 'stranglehold'. For example, an Adbusters article invokes Frankenstein to criticize how 'corporations take a stranglehold over the media landscape' (Condon 2007).

The image of corporate strangulation is also a grim refutation of Adam Smith's metaphor of the free market as an invisible hand, a metaphor still widely championed, and misinterpreted, by neoliberal ideologues today (Chomsky 1993, 412). This early scene in the film seizes on the image of Frankenstein's monster, wielder of visible, lethal, and borrowed hands, to illuminate the moment of danger posed by the crisis of corporate confidence that followed the Enron and WorldCom scandals. The Corporation was released in the wake of these scandals which, from the vantage point of 2011, look like the shape of things to come.

That the film uses footage from Lady Frankenstein and not from Whale's iconic 1931 film is a significant production detail. In several of its case studies, The Corporation criticizes the exploitation of intellectual property law by media and biotechnology conglomerates, to control 
culture and commoditize life itself. Much of the film's stock footage comes from public domain and Creative Commons-licensed material. Given the likely high cost of licensing a clip from Universal Studios, the film's use of the public-domain Lady Frankenstein saves film budget money and reinforces the movie's critique of corporate IP abuses in its very form.

As a figure of the corporation, Frankenstein's monster haunts the film. Chomsky, in another voice-over, characterizes the corporate entity's legal status as an 'amoral immortal': 'Corporations were given the rights of immortal persons, but then special kinds of persons, persons who have no moral conscience'. This characterization corresponds not to the articulate, compassionate creature of Shelley's novel, but to the mute, rampaging monster of the novel's performance adaptations, iconized by Boris Karloff in the 1931 film. Thus, the popular cultural image of Frankenstein's monster devoid of feeling, dubiously sentient, and single-mindedly destructive - has contemporary postcolonial significance as an 'amoral immortal' figure of the transnational corporation.

\section{The 'dubject' of cultural imperialism}

Applying the popular 'technological' interpretation of Frankenstein to the problematic of globalization, these Canadian films criticize the corporate institution, borrowing from Shelley's story and its popular progeny to comment, with self-reflexive irony, on communication media and their instrumentality to globalization, its hegemonic naturalization, and the 'imperialist aspirations' of transnational conglomerates (Naomi Klein, quoted in The Corporation). We see the films' selfreflexive irony most vividly in images of characters viscerally colonized and consumed by media. At the end of Videodrome, Renn seems to have followed O'Blivion into a virtual afterlife as 'the video word made flesh'; at the end of Possible Worlds, Barber becomes self-aware as a grotesquely instrumental medium of random access memory. The Corporation's collage of stock footage offers its own composite sketch of media-colonized subjectivity, between the isolated TV-viewing zombie and the mobs of hysterical shoppers. In these narratives of neoliberal globalization, the brain in a vat becomes a mutable image of subjection to global capital: an allegorical figure, both of profoundly alienated labour and of the ideal consumer - isolated, immersed, and instrumentalized.

This Frankensteinian figure of corporate subjectivity has a real-world counterpart in one tradition of Canada's 'technological nationalism', a tradition we might call dubjection: a work of being in the age of ubiquitous technological reproduction; a practice of uploading and globally distributing identity; a practice of mediatizing subjectivity itself, transcribing the improvisational experience of corporeal embodiment into the archival fixity of recording media. The dubject is a self recording and recorded, dubbed and doubled; a doppelgänger self whose 'live' presence becomes radically supplemented by its recordings and representations. For Philip Auslander, mediatization signifies the interdependence of 'live' performance and recording $(1999,198)$; among the Canadian examples I have in mind, it might signify a kind of survival.

In Videodrome, Brian O'Blivion dubjects his identity to a videotape library, becoming his own uncanny simulacrum; at the end of the film, Renn also seems to have translated himself into a cathode ray signal. This disconcertingly disembodying image of the subject's colonization and consumption by media parodies McLuhan's media theory; it also alludes to the career of Canadian pianist Glenn Gould, who abandoned live concert performances to focus strictly on studio production, thus dubjecting his public persona. The apotheosis of Gould's mediatized identity is the Voyager 2 space probe, which carries a Gould recording of Bach, with other 'music from Earth', on the ambassadorial phonograph sent with the probe (NASA 2010). Gould's dubjection still resonates in Canadian culture: Margaret Atwood adopts Gould as a namesake for the mastermind geneticist villain in her 2003 novel Oryx and Crake (84). Atwood herself has pursued a kind of dubjection, as inventor of the Long Pen, a machine that reproduces one's unique, handwritten signature at a distance; Atwood invented the Long Pen, a cyborg proxy for the author, to reduce the carbon footprint and personal stress of author book tours (see Rak 2007).

The Long Pen and the Voyager 2 probe furnish Frankensteinian icons of the technologicalnationalist dubject as an ambivalent product of cultural globalization and its corporate steering. The former keeps Atwood at arm's length from the world, while displaying the 'authentic' trace of her invisible hand; the latter engraves Gould's recording of European classical music in a dated storage 
device that may not ever be played, recruited for a space mission launched by the most symbolically imperialist institution in the USA. In McLuhan's terms, Canadian dubjectivity entails both the technological 'extension of our own bodies and senses' and the 'lease [of] our central nervous systems to various corporations' $(1964,99-100)$, both media bricolage and a redistribution that is at once infiltration and dispossession.

As a factitious, 'mosaic' identity, dubjectivity suggests the national mediascape's counterpart to its ethnoscape of multiculturalism, the Canadian state's policy that promotes 'cultural and racial diversity' (Canada Multicultural Act, quoted in Kamboureli 2000, 99) in order to practise 'diversity management', whereby 'categories of difference become integrated into a commoditized "global postmodern" space of new middle-class sensibilities ... with fascistic undertones' (Kipfer and Keil 2002, 236). For postcolonial critics, official multiculturalism amounts almost to a Frankenpheme: an experimental, ideological state apparatus that integrates Canada's culturally differentiated population in a national 'fantasy of unity', while mystifying the state's neoliberal political economy of mobilizing and managing flows of labour to sustain the flexible accumulations of global capital (Day 2000, 4; Bannerji 2000, 87).

A striking symptom of Canada's perennially imperilled sovereignty, dubjectivity reconfigures the individual citizen in a manner analogous to the ways official multiculturalism constructs the national citizenry: as the commodity of a global market, a product of competing intellectual property claims, a consumer of media consumed by media. Glenn Willmott, writing on the film adaptation of Atwood's The Handmaid's Tale, argues that 'in any story with a message about power . . . there must also be a story about the power of its medium' (1995, 184). Canada's film Frankensteins thematize and formalize this connection between message and medium, in self-reflexive representations of globalization and its handmaids in communication technologies. Canadian Frankenphemes of globalization figure national anxieties over transnational cultural imperialism in figures and scenes of bilateral media consumption, in which globalized media systems violently colonize and even consume the everyday consumer of globalized media products. To close with a stereotypically Canadian gesture of diffidence, the corpus of Frankenstein adaptations explored here represents only one national site of cultural production, suggestive - but not representative - of other postcolonial adaptations of Frankenstein. Neither are such Frankenphemes restricted to film; a recent public opinion poll described its 'statistical amalgam' of 'the qualities Canadians have told us they want in a leader' as 'an ideal political Frankenstein' (Graves 2010). Across multiple media, and among myriad sites of postcolonial popular culture, much critical work remains to be undertaken in tracking the cultural functions of Frankenstein around our volatile global village.

\section{References}

Adams, Paul S. 2007. Heimat, ein schoenes Wort, wer's recht verstuende. Paper presented at Transliteration: Literatur und Gesellschaften, 5 July, at Philipps-Universität, Marburg, Germany.

Appadurai, Arjun. 1990. Disjuncture and difference in the global cultural economy. Public Culture 2, no. 2: 1-24.

Atwood, Margaret. 2003. Oryx and Crake. Toronto: Random House, 2004.

Auslander, Philip. 1999. Liveness: Performance in a mediatized culture. New York: Routledge.

Baldick, Chris. 1987. In Frankenstein's shadow: Myth, monstrosity, and nineteenth-century writing. Oxford: Clarendon Press.

Bannerji, Himani. 2000. On the dark side of the nation: Politics of multiculturalism and the state of 'Canada'. In On the dark side of the nation: Essays on multiculturalism, nationalism and gender, 87-124. Toronto: Canadian Scholars' Press.

Beaty, Bart, Derek Briton, Gloria Filax, and Rebecca Sullivan, eds. 2010. How Canadians communicate III: Contexts of popular culture. Edmonton: Athabasca University Press.

Beller, Jonathan L. 1996. Desiring the involuntary: Machinic assemblage and transnationalism in Deleuze and Robocop 2. In Global/Local: Cultural production and the transnational imaginary, ed. Rob Wilson and Wimal Dissanayake, 193-218. Durham, NC: Duke University Press. 
Bodroghkozy, Aniko. 2002. As Canadian as ... possible: Canadian popular culture and the American other. In Hop on pop: The politics and pleasures of popular culture, ed. Henry Jenkins, Tara McPherson, and Jane Shattuc, 566-89. Durham, NC: Duke University Press.

Brydon, Diana. 2004. Postcolonialism now: Autonomy, cosmopolitanism, and diaspora. University of Toronto Quarterly 73, no. 2: 691-706.

Charland, Maurice. 1986. Technological nationalism. Canadian Journal of Political and Social Theory 10, no. 1: 196-220.

Chomsky, Noam. 1993. 'The masters of mankind': Notes on NAFTA (North American Free Trade Agreement). The nation 256, no. 12 (29 March): 412-416.

Condon, Sean. 2007. Taming the watchdogs of media concentration. Adbusters 72 (18 June), https://www.adbusters.org/magazine/72/taming_watchdogs_media_concentration.html

The Corporation. Directed by Mark Achbar and Jennifer Abbot. Vancouver: Big Picture Media, 2003.

http:/www.youtube.com/watch?v=Pin8fbdGV9Y\&feature=PlayList\&p=FA50FBC214A6CE $\underline{87 \& \text { index }=0 \text { \&playnext }=1}$

Dawson. M. 1930. Frankenstein, Inc. The American Mercury, (19 March): 274-280.

Day, Richard J.F. 2000. Multiculturalism and the history of Canadian diversity. Toronto: University of Toronto Press.

Frankenstein. Directed by James Whale. Hollywood: Universal Studios, 1931.

Gasher, Mike. 2002. Hollywood North: The feature film industry in British Columbia. Vancouver: University of British Columbia Press.

Gasher, Mike, Rowland Lorimer, and David Skinner. 2007. Mass communication in Canada. 6th ed. Toronto: Oxford University Press.

Grant, Peter S., and Chris Wood. 2004. Blockbusters and trade wars: Popular culture in a globalized world. Vancouver: Douglas \& McIntyre.

Graves, Frank. 2010. Frankenstein's ideal leader. The mark (24 March). http://www.themarknews.com/articles/1178-frankenstein-s-ideal-leader

Hitchcock, Susan Tyler. 2007. Frankenstein: A cultural history. New York: W.W. Norton.

Hughes-Fuller, Patricia. 2010. Gothic night in Canada. In How Canadians communicate III: Contexts of popular culture, ed. Bart Beaty, Derek Briton, Gloria Filax, and Rebecca Sullivan, 259-80. Edmonton: Athabasca University Press.

Ipellie, Alootook. 1993. Summit with Sedna, the mother of sea beasts. In Arctic dreams and nightmares, 34-42. Penticton, BC: Theytus Books.

Jameson, Frederic, and Masao Miyashi, eds. 1998. The cultures of globalization. Durham, NC: Duke University Press.

Kamboureli, Smaro. 2000. Scandalous bodies: Diasporic literature in English Canada. Toronto: Oxford University Press.

Kipfer, Stefan, and Roger Keil. 2002. Toronto Inc.? Planning the competitive city in the New Toronto. Antipode 34, no. 2: 227-64.

Kroker, Arthur. 1984. Technology and the Canadian mind: Innis, McLuhan, Grant. Montreal: New World Perspectives.

Lady Frankenstein. Directed by Mel Welles and Aureliano Luppi. Condor International, 1971. Repr. The Internet Archive. http://www.archive.org/details/Lady Frankenstein

Leibniz, Gottfried. 1710. Theodicy: Essays on the goodness of God, the freedom of man, and the origin of evil. Ed. Austin Farrar. Trans. E.M. Huggard. London: Routledge \& Kegan Paul, 1951. http://www.gutenberg.org/files/17147/17147-h/17147-h.htm

Marks, Laura. 2005. Packaged for export, contents under pressure: Canadian film and video in a U.S. context. In Cultural subjects: A popular culture reader, ed. Allan J. Gedalof, Jonathan Boulter, Joel Fafak, and Cameron McFarlane, 189-201. Toronto: Thomson Nelson.

McCutcheon, Mark A. 2009 Downloading doppelgängers: New media anxieties and transnational ironies in Battlestar Galactica. Science Fiction Film and Television 2, no. 1: 1-24.

McLuhan, Marshall. 1951. The mechanical bride: Folklore of industrial man. New York: Vanguard. 1964. Understanding media: The extensions of man. Corte Madera: Gingko Press, 2003. 
1967. The Medium is the Massage: An Inventory of Effects. Corte Madera: Ginkgo Press, 2001.

1969. The Playboy Interview. In The Essential McLuhan, ed. Eric McLuhan and Frank Zingrone, 233-69. Toronto: Anansi, 1995.

Montag, Warren. 2000. The 'workshop of filthy creation': A Marxist reading of Frankenstein. In Mary Shelley, Frankenstein, ed. Johanna M. Smith, 384-95. Case Studies in Contemporary Criticism. Boston: Bedford/St. Martin's Press.

Morton, Timothy. 2002. Mary Shelley's Frankenstein: A sourcebook. London: Routledge.

Mookerjea, Soourayan, Imre Szeman, and Gail Farschou, eds. 2009. Canadian cultural studies: A reader. Durham, NC: Duke University Press.

NASA. 2010. Music from earth. Voyager: The interstellar mission. http://voyager.jpl.nasa.gov/spacecraft/music.html

O'Flinn, Paul. 1983. Production and reproduction: The case of Frankenstein. Literature and History 9, no. 2: 194-213.

Pennee, Donna Palmateer. 1999. Culture as security: Canadian foreign policy and international relations from the Cold War to the Market Wars. International Journal of Canadian Studies 20: $191-213$.

2004. Literary citizenship: Culture (un)bounded, culture (re)distributed. In Home-Work: Postcolonialism, pedagogy \& Canadian literature, ed. Cynthia Sugars, 75-85. Ottawa: University of Ottawa Press.

Possible Worlds. Directed by Robert Lepage. Toronto: Alliance Atlantis, 2000.

Rak, Julie. 2007. Can(the)lit: The cultural meaning of Atwood's Long Pen. Paper presented at TransCanada Two: Literature, Institutions, Citizenship, 14 October, at University of Guelph, Guelph, Canada.

Roy, Arundhati. 2008. The monster in the mirror. Guardian, 13 December, http://www.guardian.co.uk/world/2008/dec/12/mumbai-arundhati-roy

Rutherford, Paul. 2005. Made in America: The problem of mass culture in Canada. In Cultural subjects: A popular culture reader, ed. Allan J. Gedalof, Jonathan Boulter, Joel Faflak, and Cameron McFarlane, 101-14. Toronto: Thomson Nelson.

St Clair, William. 2004. The reading nation in the Romantic period. Cambridge: Cambridge University Press.

Sassen, Saskia. 2000. Spatialities and temporalities of the global: Elements for a theorization. Public Culture 12, no. 1: 215-32.

Shelley, Mary. 1818. Frankenstein. Ed. D.L. MacDonald and Kathleen Scherf. Peterborough, ON: Broadview Press, 1999.

Sickels, Robert. 2009. The business of entertainment: Movies. Santa Barbara: ABC-CLIO.

Slusser, George. 1992. The Frankenstein barrier. In Fiction 2000: Cyberpunk and the future of narrative, ed. George Slusser and Tom Shippey, 46-71. Athens: University of Georgia Press.

Videodrome. Directed by David Cronenberg. Toronto: CDFC and Famous Players, 1983.

Willmott, Glenn. 1995. O Say, Can You See: The Handmaid's Tale in Novel and Film. In Various Atwoods: Essays on the Later Poems, Short Fiction and Novels, ed. Lorraine York, 167-90. Toronto: Anansi Press.

World Social Forum. 2002. Charter of principles. http://www.forumsocialmundial.org.br/main.php?id menu=4\&cd language $=2$ 